\title{
More than just a piece of land: Power dynamics in the land discourse within the City of Tshwane ${ }^{1}$
}

\section{Thinanadvha D Mashau²}

\begin{abstract}
Land ownership in South Africa is a thorny issue. The magnitude of this challenge is so huge that we are like a country sitting on a time bomb which is already ticking and ready to explode. Whilst it remains a dream of every South African to own a piece of land, the government has been slow to deliver to its promise. This article seeks to explore the issue of land and dispossession from the perspectives of those in the margins, the homeless in the City of Tshwane. This is done by allowing them space to read and reflect on 1 Kings 21:1-16 and apply it in their context of landlessness. Emerging voices of ordinary readers of the text, as represented by the homeless in the City of Tshwane, suggest that land ownership is more than just a commercial issue; it involves such issues as culture, politics and religion, amongst others. Power dynamics are at play, especially with regard to the right to the City. There is also an issue of attachment, especially when issues of ancestry and birthrights are raised.
\end{abstract}

Keywords: Land, Discourse, Homeless, Power dynamics, City of Tshwane

\section{Introduction}

"This land belongs to our ancestors; it is my birthright and my heritage," exclaimed one of the participants in the Meal of Peace project of the University of South Africa. Another participant added her voice by saying, "I am an African, this is Africa, ... so it is my land, my identity." These are the marginalised voices of the homeless people in the streets of the City of Tshwane. They reveal deep-seated emotions of the majority of blacks who are still landless and homeless twenty years into the democratic dispensation. Their utterance points to the underlying power dynamics at play when talking land dispossession in the South African context.

1 This article was published as a chapter in the peer-reviewed book Pavement Encounters for Justice: Doing Transformative Missiology with homeless people in the City of Tshwane (Mashau \& Kritzinger 2014), that was a result of the Meal of Peace Project of the Dept. of Christian Spirituality, Church History and Missiology at Unisa. The editors and the authors (as copyright owners), have given permission that this version may be published in Missionalia, as an accredited South African journal

2 Prof TD Mashau is a lecturer in the Department of Christian Spirituality, Church History, and Missiology at the University of South Africa. He can be contacted at mashatd@unisa.ac.za 
It is clear from their utterances that land ownership remains a thorny issue in this country. We are like a country sitting on a time bomb which is already ticking and ready to explode or we are like a country on the brink of experiencing a spring of our own in the same mode as the Arab spring. In his book, entitled A Rumour of Spring: South Africa after 20 years of Democracy, Max du Preez (2013:159) echoed the same sentiments: "No national issue elicits as much anger, fear and fiery confrontation as the ownership of land." Intense emotions flow whenever the issue of land is raised. It is impossible for many Africans to separate the issue of land from colonialism and apartheid and each time that the question of land ownership is raised, many are reminded of that past. This is reflected in the following words: "Apartheid is a story of a dispossessed people. The story of land robbery. The story of colonialism, bloodshed, and national dispossession of the people on a scale unparalleled and unprecedented in the history of Africa" (Pheko 1984:1).

The aftermath of such land dispossession was dire and devastating for the Africans. The Twenty Year Review (2014:2-3) identified, amongst others, the following: (1) systematic stripping of blacks of their human dignity; (2) loss of independence as blacks were subjected to white rule; (3) lack of mobility in terms of free movement in their [blacks] country of birth. Blacks were allowed free movement in the reserves whilst they were allowed to move into white settlements as cheap labourers whose movements were closely monitored even through legislation; and (4) Africans were stripped of the rights to purchase, own, lease or use land, except in "reserves" for African people. The effects of land dispossession in South Africa are still felt twenty years into democracy and this also applies in the context of the homeless and landless in the City of Tshwane. Evictions and relocation of the homeless from one place to another is not something of the past. The eviction of residents from Schubart Park and Woodlane Village by the City Council and the court cases that followed thereafter can serve as examples of this reality. The tension that exists between city officials and the homeless is a power struggle as to who has the right to urban spaces. This is captured by Huchzermeyer (2011:244f):

Whether consciously or not, informal settlement communities resisting relocation, or mobilizing to confront repressive legislation, are fighting for a right to the city in all three dimensions: firstly, the right to longterm habitation of the city and to spatial centrality; secondly, a right to voice or participation, through access to central decision-making; and thirdly, a right to the oeuvre, the creative making of public spaces in the city after one's own desire, and without consideration for their 
productive utility - in the post-millennial context, utility for urban competitiveness.

It is clear from the foregoing that contestation for the right to a city like Tshwane remains very much a feature of the current political landscape in South Africa. No wonder De Beer (2008:185) concluded that:

$[T]$ he spatial arrangements in the inner city tell stories of local culture and counterculture; of monuments to exalt political and economic powers; of who are welcome in a particular community, and who are not. The stories express the prejudices of local residents, politicians and business.

In the light of the aforementioned, this article seeks to explore the issue of land and dispossession from the perspectives of those on the margins, homeless people in the City of Tshwane. This is done by allowing them space to read and reflect on 1 Kings 21:1-16 and apply it in their context of homelessness and landlessness. The main research questions that we paid attention to are: How do the homeless people of Tshwane encounterologically read and apply 1 Kings 21:1-16 in their context? What power dynamics did they unearth or identify from the text which are also relevant to their homeless and landless experiences? What lessons can be drawn from their interpretation and application of this text? What is the missiological thrust of this reflection? What role can the church play to address the issue of homelessness, landlessness and power dynamics in the City of Tshwane?

To answer these questions, this article will reflect on the following issues: (1) literature review on landlessness and power dynamics in the City of Tshwane, as our theoretical framework upon which the entire research is built; (2) the research methodology applied; (3) theological reflection of 1 Kings 21:1-16 as a way to map out how trained or learned readers (theologians) unearthed issues of land dispossession and power dynamics in this text; (4) encounterological reading of 1 Kings 21:1-16 dealt with, in order to allow the voices of the voiceless and marginalised to be heard in the discourse about land dispossession and power dynamics; (5) synthesis: emerging voices of the marginalised will then be recorded. And the article will be concluded by providing a summary of what is considered to be a solution, provided by the homeless people of Tshwane, regarding the issue of land dispossession and power dynamics in their encounter with the Biblical text and their immediate reality. 


\section{Landlessness and power dynamics in the City of Tshwane}

\section{Landlessness in the City of Tshwane}

As we celebrate twenty years of democracy in 2014, the question of land reform remains one of the hotly-debated issues within the political landscape of South Africa. The "willing buyer, willing seller" policy of the ANC-led government did not do much in terms of redressing inequalities of the colonial and apartheid past in this area. In his article, "Willing buyer, willing seller': South Africa's failed experiment in market-led agrarian reform", Edward Lahiff (2007) explores the failures of such a policy in a comprehensive way. Whilst this policy sought to entrench the spirit of the Freedom Charter of 1955, "South Africa belongs to all who live in it, black and white" and the spirit of reconciliation in the rainbow nation of Nelson Mandela, it failed dismally in terms of returning land ownership to its rightful owners.

A new kid on the block in the South African political landscape, the Economic Freedom Fighters (EFF), seized the moment when they unashamedly called for "land expropriation without compensation" in the same spirit as that of ZANU-PF in Zimbabwe. The land issue tops the agenda of the EFF and their founding manifesto highlights the issue on "expropriation of South Africa's land without compensation for equal redistribution in use" as a priority issue (Shivambu 2014:128). This has left the country even more polarised than before. The polarisation is not just between blacks and whites; the "black diamonds" who serve the interests of white capital remain sceptical to pronouncements of Julius Malema and his fighters. Whilst many fear that the country will go the same route as Zimbabwe, others feel that theirs is just an elusive dream that will never come to pass. To the white community - and white farmers in particular the issue of land speaks to the issue of identity on the one hand and the question of livelihood on the other (see Du Preez 2013:160). But this is not just a question of black and white, seeing that it is not every white person who owns land. According to Shivambu (2014:4), "The ownership and control of arable land in South Africa is not only a black and white issue (which it vividly appears to be), but a class reality where less than $2 \%$ of the white population are in ownership and control of vast tracts of South Africa's land." In his article, "Mission as action in hope in the context of white poverty in Pretoria: A case for Betlehem mission centre", Mashau (2012:59) points out the reality of a growing number of whites who are 
homeless (and by implication also landless) and living in streets, shelters and informal settlements like Betlehem in the City of Tshwane.

Faces of landlessness in the City of Tshwane are diverse and varied. The following can serve as examples to illustrate this truth: (1) areas such as Mamelodi, Atteridgeville, Ga-Rankuwa, Hammanskraal, Soshanguve and Mabopane (among others) remain symbols of apartheid, created for blacks who were used as cheap labourers in the white-run economy. Except for the emerging middle-class elite group among blacks, the majority of black Africans cannot afford to work and live in the emerging suburbs and super-suburbs of the city. They are still forced to take taxis and buses back to these apartheid-created settlements on a daily basis; (2) the homeless who live in the streets of our city remain symbols of landlessness; (3) as a result of growing urbanisation, informal settlements such as Mooiplaas in our city also remain symbols of landlessness in our midst; (4) those who invade and hijack dilapidated buildings like Schubart Park (four twenty-storey buildings that became the worst high-rise slums in the City of Tshwane before residents were evicted in September 2011) are also the face of landlessness in our city; and last but not least, (5) the indebted owners of houses are also landless. These are people who, on the surface, look to be legitimate owners of houses whilst in essence their houses are owned by the capitalist system. We can also list in this category those who are either renting or leasing properties in the city, except those (including business people) who do so voluntarily. Unlike the street homeless in our city, this last group can be labelled as commercialised homeless people. The only difference is that, after having been exploited by paying more than the amount said to be the value of the house, commercialised homeless people have an opportunity to become home owners, thereby affording them the opportunity to become land owners once they receive their title deeds.

\section{Homelessness and landlessness in the City of Tshwane}

As in all other cities in South Africa, homelessness remains a serious challenge in the City of Tshwane. The homeless see lodging opportunities in every piece of land that they see. They sleep everywhere; you get them in front of government buildings, business stores and offices, dilapidated buildings in the city, shelters, streams and nearby bushes, and many informal settlements in the city which are their own inventions. Some even hijack empty office buildings in the inner city and convert them to become 
their homes that they even rent out to others (see De Beer 2008:185). When you look at this complex phenomenon in the City of Tshwane, there are a few things that deserve to be mentioned:

Firstly, homelessness knows no limits of race, age, gender and class or even nationality. The homeless population is not homogenous (Maiwane et al 2010:48). Blacks, whites, men, women, youth, children, locals and foreigners have all become the faces of homelessness in the City of Tshwane. Secondly, there are different groups of homeless people that can be identified, namely: "detached homeless persons, temporary overnight sleepers (including evictees and "weekday' homeless persons), and informal settlement dwellers" (Du Toit 2010:3). As a result, Du Toit (2010:3) concluded that: "The first two of these three groups can be referred to collectively as 'street homeless persons', since they typically live on the streets of metropolitan municipalities." Thirdly, the reasons for homelessness are diverse and complex. Fourthly, the homeless in our midst live in inhumane conditions. And lastly, we need to understand that whilst there is some overlap between homelessness and landlessness, not every person who is homeless in the City of Tshwane is landless. Because of migration and other push factors such as employment opportunities in the city context, many people move away from rural areas in South Africa and other African countries where they own pieces of land to come and live in the city, only to end up temporarily homeless - but not necessarily landless.

\section{Landlessness and power dynamics in the City of Tshwane}

The struggle for land is a present reality in the City of Tshwane. The situation is so serious that De Beer (2014:1) concluded that the struggle for land is a matter of life and death. The struggle experienced by the street homeless, those in shelters and in informal settlements in the City of Tshwane reminds us of this truth. It is a struggle "for the right to the city, but more essentially for being human" (De Beer 2014:1) and indeed a spiritual battle for the soul of the city, as outlined in the introduction. This struggle for the right to the city is captured by De Beer (2008:183-184) as follows:

Inner-city is permanently contested. There is a battle between local authorities, private developers, slum landlords, civic organisations, resident groups, landless groups, informal traders, drug pushers, and drug users all wanting to appropriate inner-city space for their own purposes.

This contestation takes place on a daily basis (Kritzinger 2008:338) and everyone involved finds ways to be as creative as possible in order to 
survive or even achieve their purposes. Mashau (2014:1) concurs that "the city is a creative space, which is paradoxically placed. It is a contested space where hills in it constantly change its landscape; the hills also use their powers to hide the valleys and streams therein." The struggle for the right to the City of Tshwane is varied and complex and the following examples can be cited:

(1) The struggle between Woodlane Village residents and the Residents Association that sought their removal (see De Beer 2012:253). Woodlane Village is the informal settlement located on the doorstep of the NG Church Moreleta Park, Woodhill Golf Estate and college, Mooikloof Estate and Woodlands Boulevard. De Beer (2012:253) noted three power dynamics at play in this instance. Firstly, it is the struggle between the wealthiest landowners in Tshwane (which will include businesses as well) and the squatters. Wealthy landowners and businesses in this vicinity are afraid that the presence of the squatters will devalue their properties. Secondly, it is the struggle between the squatters and the City Council, who were instructed by the court ruling to create an integrated development plan, in the effort to eradicate this informal settlement without the exclusion of its residents (De Beer 2014:3), something which has not yet been implemented by the City Council. Thirdly, it is the struggle between people of faith, an issue to which I come back later when concluding this section.

(2) The much-publicised struggle between residents of Schubart Park and the City Council (De Beer 2014:3).

(3) The announcement by the Health and Social Development Departments of the City of Tshwane in June 2014 that they would evict residents at Number 2 Struben Street caused a great stir amongst the homeless and the City of Tshwane (Van Zuydam 2014a). Number 2 Struben Street is a shelter managed by the City of Tshwane to provide temporary accommodation for the homeless. It is located on the corner of Struben and Kgosi Mampuru streets.

(4) Criminalisation of homelessness by SAPS and metro police. In their efforts to clean up the city, SAPS and Metro Police regularly take some of the homeless and street vendors to their holding cells or dump them at the homeless shelters, especially Number 2 Struben Street. Whilst responding to the imminent evictions of Number 2 Struben Street, the chairperson of Tshwane Forum for the Homeless, Stephan de Beer, commented: "It is appalling to see how this facility has deteriorated over time and has become a dumping ground for SAPS and Metro to simply clean people off the street as if they are waste" (Van Zuydam 2014a). In some instances, cooperation between private 
security companies like the Red Ants and the Metro Police is used to dislocate residents of unwanted informal settlements in the city. This is what Huchzermeyer (2011:53) calls "the approach of outsourcing informal settlement 'management' to security companies."

(5) The campaign "Taking back our streets!" (De Beer 2010:1). It is the campaign driven by Tshwane Leadership Foundation annually. It is not a campaign to clean up in order to get rid of the homeless in the streets of Tshwane, but one that seeks to address their plight and bring back their human dignity. It is captured by De Beer (2010:1) as follows:

"Taking back our streets!" is used as a metaphor for that which was lost and is reclaimed, both personally and collectively: our dignity, our voices, our bodies, our agency; our streets from crime, our parks and public places for our children; our ability to participate in public processes that shape the future of our neighbourhoods.

Examples cited in this section were not meant to be exhaustive, but rather to help us to understand the complexities of landlessness and power dynamics at play within the City of Tshwane. It helps to lay a solid foundation for this research, a basis upon which the voices of those in the margins can be heard as they reflect on the question of land dispossession and power dynamics from 1 Kings 21:1-16.

\section{Church, homelessness, landlessness and power dynamics in the City of Tshwane}

Contestation in the City of Tshwane is not only for the right to the city, but is also a spiritual battle. This is captured in the following words: "Essentially, the battle for space is a spiritual battle (in the broad sense of the word). It is a battle for the soul of the city, a battle of values with profound political, socio-economic, cultural and even moral considerations" (De Beer 2008:185). Mashau (2014:4) concurs that: "it [the city] is a war zone space where there are both physical and spiritual casualties." But the question is: What is the role of the church in the context of land dispossession and power dynamics in the City of Tshwane? Responses vary from one church community to another, but we can conclude without fear of contradiction that this matter has divided Christian communities in the City of Tshwane. (1) Some churches exercise the "ministry of absence" and "exclusion" of those in the margins, whilst others do not. This is what Stephan De Beer (2014:4) calls "disembodied presence":

Many urban churches represent such a 'disembodied presence'. When we are present to each other in a way that does not truly create or allow space for 'the other', the insularity of our presence accentuates 
the absence of 'the other'. When our presence is so overwhelming that it overshadows the weaker voices of the poor, vulnerable girls, illegal asylum-seekers or informal street traders, it is a presence that should preferably have been kept at bay as it accentuates our strangeness; it becomes a 'heavy' presence, an unwanted presence.

In the struggle for urban spaces, in some instances churches are caught between their support for the powers-that-be in the city over against their support for the homeless and landless. Speaking about the Woodlane Village case, De Beer (2012:253) noted that:

On both sides of this contest for space are people professing to be Christians. The largest church in the city is separated from Woodlane Village's 3,500 residents by a simple fence. What is the gospel in such a fragmented urban context, in the contest for land and space? And how does it inform our understanding and practice of theological education?

It should be noted, as we conclude this section, that some churches have exercised a ministry of presence in a real sense of the word. They walk alongside those who are in the margins and provide for their needs. There are many shelters in the City of Tshwane that are faith-based and are doing their best to minister to the homeless in our midst. Tshwane Leadership Foundation is one such faith-based organisation in the city which is working with churches and communities for urban transformation. They run such ministries as the Potter's House for women in crisis, Lerato House for girls at risk, Akanani which addresses homelessness, and Inkululeko Community Centre (www.tlf.org.za).

\section{Research Methodology}

As already noted, this article seeks to look closely at the issue of land dispossession and power dynamics through the eyes of the homeless in the African City of Tshwane, in terms of how they read 1 Kings 21:1-16 "encounterologically" and apply it in their own situation of landlessness. In the effort to reach this objective, a descriptive study was undertaken within the framework of participatory action research aimed at "seeking justice in the context of homelessness" in the African City of Tshwane. It should be noted at this point that a study of this nature has limitations of its own. Apart from having limited recorded sources on land dispossession in the City of Tshwane, not all the homeless of Tshwane could be reached and contacted to participate in the project. In this study, 23 informants (7 males and 16 females) participated in the whole process. In line with the Contextual Bible Study (CBS) methodology of Gerald West and Ujamaa Centre Staff, participants were allowed space to read 1 Kings 21:1-16 to get a sense of 
what the text is all about. The text was read out aloud by a participant with a clear audible voice. This is very important because there might be people within the group who are not fully literate. Participants were then requested, without being coerced, to volunteer and enact a drama to relive the story of 1 Kings 21:1-16.

After the completion of the drama to relive the text, the entire group was allowed space to respond to structured questions. In line with the CBS methodology, Question 1 was written on a newsprint and participants were invited by the researcher (who acted as a facilitator) to "buzz" with their neighbour concerning what they think the text is about. By discussing the opening question in buzz-groups, the ice is broken since every participant is able to share something. Participants discover here that it really is "okay" to say whatever they want. After about five minutes, the researcher called for responses to the first question. Everybody was given the opportunity, but not coerced, to speak or respond. Each response is summarised by a notetaker on newsprint, in front of all participants. The facilitator made no judgements or comments except to encourage participants to share their responses and to expand on them if not clear. When everyone had an opportunity to make a contribution, the process moved on. Focus groups of no fewer than five persons each were then given space to discuss the rest of the structured questions together. This proved to be a useful instrument in data gathering. Greeff (2010:360) agrees that focus groups are "a means of better understanding how people feel or think about an issue, product or service." Each group appointed a scribe and a reporter to give feedback to the larger group. At the end of the session, the researcher (facilitator) collected all the newsprints to be captured as primary data and what follows below are the outcomes of the entire process (research findings).

To avoid unethical behaviour on my part as a researcher (see Strewing \& Stead 2001:67), all participants (informants) were informed of the nature of this research and their consent was sought, with the understanding that this work would be published in the form of a scholarly manuscript or article. All informants were willing participants in the whole process of data gathering and the synthesis thereof.

\section{Theological reflection of 1 Kings 21:1-16 on land and dispossession}

A theological interpretation of 1 Kings 21:1-16 on the issue of land dispossession and power dynamics should be placed within the wider Old Testament scope regarding issues of land, dispossession, distribution (and related matters). It will be difficult within the scope of this article to exhaust 
this matter; but an attempt to highlight some Biblical principles and guidelines regarding the issue at stake will prove valuable for our understanding and interpretation of 1 Kings 21:1-16. Some of the key Biblical principles and guidelines regarding land and related issues can be summed up as follows: (1) the overall picture that the Old Testament gives is that the land belongs to God. Leviticus 25:23 is very articulate on this matter: "The land must not be sold permanently, because the land is mine and you are but aliens and tenants." This is an overriding principle that the Israelites were to keep in mind in all their activities regarding land. God is the sole owner of the land; it is his property. This, according to Battle (2008:18), is consistent with the nature of God, who is always projected in Scripture as the owner of all the earth and everything in it; (2) human beings are seen as custodians of God's land. Human beings are therefore to serve as caretakers who should exercise their stewardship in obedience to the Lord, the owner of the land. In the Old Testament, land was something that was promised to God's people as their inheritance (see Exodus 20:12; cf. Kaiser 1981:302, 305). Land has always been projected as God's gift to his people; (3) ownership, dispossession and distribution of land should therefore be conducted in line with the two principles above. Human beings do not have absolute control over the land; they must subject themselves to the authority of God. This is captured in the following words of Battle (2008:19): "Yet humans are not supreme. As Creator and Judge, God continually exercises his prerogative over the lives, welfare, and wealth of people and nations; and therefore all people are held accountable to him for the use of their own property." The principles and guidelines outlined above are not meant to be exhaustive, but they provide enough basis to engage 1 Kings 21:1-16 theologically.

The narrative about land dispossession in 1 Kings 21:1-16 took place during the reign of Ahab in Samaria. Ahab had two palaces, one in Samaria and another in Jezreel, beside the vineyard of Naboth the Jezreelite, as recorded in 1 Kings 21:1. Apart from drawing our attention to the location, this narrative opens by pointing out King Ahab's desire to possess the land (vineyard) of Naboth the Jezreelite (1 Kings 21:2). Contrary to the customs of his contemporaries, Canaanite kings had powers to seize land at free will, but the narrative points out that King Ahab negotiated with Naboth to either exchange the piece of land for another one or to receive payment for it. It is clear that Ahab negotiated with Naboth because he knew of the God-given principle which guides such transactions - that the land belongs to God. This is one point about which Naboth reminded the king in the following words: "...The Lord forbids that I should give you the inheritance of my 
fathers" (1 Kings 21:2). Whilst it is impossible to provide a comprehensive exegesis of this text in this article, it is critical to note that our interest is on the issue of land and dispossession; and therefore we are compelled to ask one question: What are the theological underpinnings that 1 Kings 21:1-16 provides with regard to land and dispossession?

Firstly, on the question of land and land possession, 1 Kings 21:1-16 clearly affirms the fact that land belongs to God, and human beings only act as custodians. Secondly, on land dispossession, 1 Kings 21:1-16 points out various power dynamics at play and the following are noteworthy: (1) The desire to have more land, which portrays an element of being driven by material possessions (materialism) and greed, pushes people to disregard God-given principles on land issues. King Ahab stooped so low as to beg for more land from Naboth, even when he was consciously aware of the Deuteronomistic History regarding the matter - hence his approach not to seize the land, but to try and negotiate for it; (2) Power abuse comes to the fore when Jezebel, realizing that King Ahab did not get the land from Naboth, appealed to the authority of his Kingship over Israel (1 Kings 21:7). Jezebel was raised as a princess of King Ethbaal of Sidonia (Phoenicia) and she knew very well that the King has the authority over his subjects on everything. It is asserted that: "In Canaanite nations, a king could seize property and personal belongings at pleasure, because in theory all the property was owned by the royal family and only entrusted to their subjects" (Sproul 2005:509). Jezebel was not privy to such texts as Leviticus 25:23, where God is projected as the owner of the land. Jezebel not only appealed to the powers that the King had (1 Kings 21:7), but she also plotted to get the land from Naboth by hook or by crook. She made use of the seal of the King to convene a meeting that ensured that the land was taken from Naboth; (3) Oppressive structures which are exposed in the course of this narrative. The elders, leaders and false witnesses who participated in the whole scheme are a symbol of oppressive structures in society that are manipulated to advance the cause of the rich and powerful; (4) The fact that the elders, leaders and false witnesses went along with Jezebel's plot shows how corruption can be used as a tool to expropriate land from others; (5) The use of religion as a means to exploit and oppress others is unmasked when Jezebel called for a fast. 


\section{Encounterological reflections on 1 Kings 21:1-16 on land dispossession and power dynamics}

When asked what 1 Kings 21:1-16 was all about, respondents [the group of homeless (some landless) from the City of Tshwane] concluded that the text is about:

- the power to take land from the weak;

- the power of money - you can buy all that you desire;

- abuse of power;

- those who are close to those in power can abuse power;

- power and influence;

- class issues (important and less important people);

- protecting an inheritance and belonging;

- manipulation of prayer and fasting;

- selfishness and deceitfulness;

- the land was Naboth's birthright;

- possession and power;

- land and peace; jealousy;

- land, history and dignity.

The responses above already give you an indication that the homeless in the City of Tshwane, who were respondents of this project, varied from those with little or no education to those who, for financial reasons, could not continue with their studies but have knowledge and a comprehensive vocabulary to understand and engage with the given text and also apply it in their context.

As for the question on the main characters in the text and what they know about them, respondents correctly identified King Ahab, Jezebel and Naboth as the main characters in the narrative. Groups 3 and 4 added the official (as recorded by Group 3), elders (as recorded by Group 4), and citizens of Jezreel. In terms of what they know about each of these characters, there is consensus in terms of how they see the roles of King Ahab and his wife Jezebel. King Ahab is said to be a ruler who was greedy or selfish. He was someone who ruled with an iron fist and was influenced by his wife, as recorded by Group 2. Jezebel, on the other hand, was characterised as the King's wife, cruel and self-centred. Group 1 pointed out that she plotted to kill Naboth, whilst Group 2 added that 
she was "possessed by demons, [a] cunning and manipulative, control freak." The officials and leading citizens are the ones who accused Naboth of cursing God and the king. Naboth, on the other hand, is understood to be the owner of the vineyard next to the king's palace. Group 3 expanded on this, saying that: "Naboth [was a] humble man; he was a law-abiding citizen who was God-fearing; he was not influenced by monetary treasures; he valued his land; he was a straight talker (didn't beat about the bush)." Group 4, on the other hand, brought the issue of ancestry into the entire debate about land ownership as follows: "Naboth owned a piece of land that he inherited from his ancestors."

In their reflection, participants were able to identify the vineyard's proximity to King Ahab's palace as the reason why he wanted Naboth's vineyard. All the four groups agreed that the King also wanted the piece of land as a vegetable garden. It was Group 2 that added the element of greed when they said: "He just wanted to accumulate (more) land." And as for the reason why Naboth did not want to sell his vineyard to Ahab, all participants raised the issue of inheritance. They all agreed that it was an inheritance from his ancestors. Group 2 added that "It was his birthright" and that "He wanted to pass it on to his loins (his children's children)." Group 3, on the other hand, raised the issue of faith when noting that: "The Lord forbids that he should let the king have his inheritance."

As for the strategies which Ahab used to dispossess Naboth of his land, participants agreed that he used both lawful and unlawful means. The king negotiated with Naboth to offer him money or alternatively offer him a better land for use as a vineyard. These were lawful strategies according to the participants. Failing to convince Naboth to sell his vineyard, participants noted that Ahab reverted to unlawful means with the help of his wife Jezebel. Jezebel, according to Group 2, "wrote a letter to manipulate the officials and the leading citizens of Jezreel" and as a result Naboth was falsely accused and stoned to death. It was only after these actions that Ahab was able to dispossess Naboth of his land.

Participants noted race, class and ethnicity played a role in the unfolding of this story. On the question of race, Group 1 and 4 pointed out that Naboth was a Jezreelite whilst Ahab was a Samaritan. On the question of class, Group 1 noted that Ahab was a king [and] Naboth was an ordinary person. Group 2 agreed that Ahab had power and wealth, and therefore the king knew that his word was final. They branded him as a dictator who is above the law. According to Group 3, "Ahab used his social standing to take land from the weak." On the question of ethnicity, it was only Group 4 that appealed to his ancestry as the reason for his refusal, as a sign of being conscious of one's ethnicity. 
After all the groups had given their reports, as recorded above, the facilitator encouraged the participants to think how power dynamics are at play with regard to land and its dispossession. They were encouraged to seek the link between land, one's history of dispossession [with particular reference to the history of land dispossession and power dynamics in South Africa] and how it connects with their current situation of homelessness and landlessness [to some]. Groups were then instructed to return to their small groups and questions 7, 8, 9 and 10 were put up on newsprint. Each group dealt with only one assigned question and the following findings were recorded in the newsprint and reported by the reporters in the larger group [research findings]:

On the question as to why and how people in their community have lost land, Group 1 enumerated the following reasons: "Lack of power, unemployment, poverty, race and colonisation." As for how the land was dispossessed, they cite the passing of the "Native Land Act (1913)" as a means by which land was taken from black people. They also mentioned that government corruption has contributed in a big way to the loss of land in some instances. Group 2, which dealt with the question as to why land is your land, pointed out that this land belongs to their ancestors. "It is my birthright and my heritage," exclaimed one of the participants in this group. Another one asserted by saying that: "I am an African, this is Africa, [and] so it is my land, my identity."

As to how they plan to regain their land, Group 3 plans to take the government and those who dispossessed them off their land to court. They also intend using the political power and government money to regain their land. In addition, and together with all the other groups, participants came up with a plan of action which includes, amongst others: communal concerns about land must be considered by government; the government must solve housing/land issues with citizens; they must break away from boundaries of class and race; support and grow the models of bringing the poor into [the] city through social housing schemes; the government must seek to empower the homeless with skills and jobs for them to be able to buy and own land of their own; and, lastly, they wanted all policies [regarding land] in the country to be revised.

\section{Synthesis: Emerging voices of the ordinary}

The process of bringing synergy between the trained (learned) reader and the ordinary reader of the text is one critical step in allowing space for the voice(s) of the ordinary reader to emerge. It is a necessary step because it allows space for interfacing between the trained (learned) reader and the 
ordinary reader of the text, as proposed by West (1995:209). When doing synthesis in this case, it became clear that participants in this research [ordinary readers of the text] understood what 1 Kings 21:1-16 was all about. There are three things in common that can be outlined between the two readers, namely: (1) the text is about land and dispossession; (2) land is more than just a piece of land - it is an inheritance from ancestors. There is serious attachment to the land as a land of birth (birthright); (3) the use or misuse of power to dispossess land from others. The only difference that one can glean from the foregoing is that ordinary readers of the text were not able to make an appeal to Biblical texts that reveal God as the owner of land, with human beings as custodians.

The ordinary readers of 1 Kings 21:1-16 view the text as a spiritual guide to understanding the issue of land, dispossession and power dynamics. There is a clear indication that the participants see the Bible as a book of liberation, one that they are able to use to speak to their context. The participants have shown great interest to use the liberatory nature of the text as a resource to unlock their struggle as homeless and landless people. In the course of engaging 1 Kings $21: 1-16$, participants came up with the following proposals as a remedy to their immediate city context, results which can be applied anywhere in the country (rural areas included):

- There is a need for Africans to reclaim their land. In this case, they proposed such measures as taking government to the constitutional court as a strategy to seek recourse to their plight of being landless. It is for them a matter of justice and trying to restore their human dignity as Africans.

- They proposed a participatory process in terms of the government trying to resolve land issues. All stakeholders must be part of the solution, including the homeless in the City of Tshwane. This is a valid point to raise, especially when taking into consideration that the government has often by-passed the process of consulting with those in the margins, in favour of a top-down approach that would have taken seriously the business model, with funding coming mainly from central government instead of tapping into local resourcefulness. The exclusion of the homeless in the process robs them of their space to learn and be empowered to be self-reliant. It is asserted that, as a result of minimal consultation from the government, "communities may have lost an opportunity to develop experience of and capacity for self-delivery" (Cross 2013:243).

- Government must not only listen to the plight of the homeless, but also empower them towards land ownership through skills training and job creation. This is what even those who are in the academia 
are proposing. Part of the agenda which the government should embrace is therefore to create space for economic access to the poor and increasingly map a way "to bring the excluded poor into the cities with affordable shelter, in spatial locations where livelihoods are accessible" (Cross 2013:243). Looking at the context of the homeless who were part of this project, the government can learn and collaborate with institutions such as Tshwane Leadership Foundation and the University of South Africa [through the Meal of Peace Community Engagement Project] which are empowering these people with skills to be more self-reliant.

- Government must be encouraged to curb corruption and do away with class and race issues in resolving the land issue in South Africa. Justice should therefore be meted out to those who are involved in such activities. This is consistent with God's justice meted out to Jezebel and Ahab for killing and dispossessing Naboth of his ancestral land. The homeless in this case have a point, because those who continue to act unjustly continue to delay justice for the homeless as well. Hence the popular saying: "Justice delayed is justice denied'.

- Government and all the stakeholders (the homeless and private sectors included) must seek to initiate and support social schemes and models that seek to integrate the poor in the city through social housing schemes - even though the problem of ownership will still be a problem [title deeds will remain in government hands in case of social housing schemes]. One example to follow is that of " $[\mathrm{t}] \mathrm{he}$ Tshwane Leadership Foundation's Yeast City Housing [which] offers decent, affordable social housing in various areas of the city' (Van Zuydam 2014b).

- All policies regarding land must be revisited and revised to attend to the plight of the homeless in the City of Tshwane. The same can be applied anywhere in the country.

It is striking to note that, whilst the ordinary readers of 1 Kings 21:116 wrestled to interpret this text and apply it in their daily struggles, they were silent in terms of what they see as the role of the church or Christian communities in ministering to their context. Whilst they were able to identify the Bible as a liberating tool, they were not able to map out how best religion could be used to fight their struggles. Urban researchers and practitioners in the City of Tshwane help us to complement what the ordinary could not achieve, by unmasking the missionary role of the church in the context of landlessness and power dynamics. Faith-based communities are urged to become 
alternative communities to the plight of the marginalised - the homeless and landless in this case. This calling is outlined by De Beer (2008) as follows: "In the contest for urban space and land, I can imagine a fighting God who in Jesus Christ enters urban spaces that were exploited to claim them for the poor of the world. I can also imagine the sanitised church being at odds with the messiness of the church of the poor"; hence Mashau (2014:11) came to a conclusion that: "[m]ission in the hills and valleys of Tshwane is working with God as the great 'leveller' (justice-bringer) in society hence the call to re-imagining mission in the public square by engaging these hills and valleys."

\section{Conclusion}

The encounterological reading of 1 Kings 21:1-16 by the homeless of Tshwane brings us to the following conclusion: land ownership is more than just a commercial issue - it includes such issues as culture, politics and religion among others. Power dynamics are at play and, therefore, to redress the injustices of the colonial and apartheid past, the homeless in the streets of Tshwane require social, economic and political powers. Those with political powers like the government should therefore work with the homeless and all other stakeholders to resolve the issue of land dispossession in the City of Tshwane, efforts which can be replicated elsewhere in South Africa. The homeless in Tshwane are seeking for justice to be served in their midst by being afforded not only the political power to resolve the issue of landlessness, but also educational and economic powers when armed with necessary skills and jobs so that they are able to buy their own land and houses. The Bible should also be used as a liberating tool in restoring the dignity and pride of the homeless, as decent jobs and affordable housing are sought as practical solutions to their problems. Last but not the least, partnership between the homeless, the City of Tshwane, business, faith-based communities and all other stakeholders will prove valuable in the eradication of homelessness in the City of Tshwane.

\section{Bibliography}

Battle, J.A. 2008. Property rights and responsibilities in the Old Testament, in WRS Journal 15:1 (February 2008): 14-27.

Cross, C. 2013. Delivering human settlements as an anti-poverty strategy: Spatial paradigms. In Pillay, U., Hagg, G. \& Nyamnjoh, F. (editors). State of the Nation: South Africa 2012-2013. Cape Town: HSRC Press. 
De Beer, S.F. 2008. Contesting inner-city space: global trends, local exclusion/s and an alternative Christian spatial praxis. Missionalia 36(2/3): 181-207.

De Beer, S.F. 2010. “Taking Back our Streets": Reading Steve Biko's "Black Consciousness and the Quest for Humanity" on the Streets of Tshwane. Papers presented at the Forum for Religious Dialogue Symposium of the Research Institute for Theology and Religion held at the University of South Africa, Pretoria, 23-24 August 2008. http://hdl.handle.net/10500/4331 [Accessed 09 November 2014].

De Beer, S. 2012. Urban South Africa: An opportunity for liberating theological education. Missionalia 40(3): 251-277.

De Beer, S.F. 2013. Absence, presence, remembrance: A theological essay on frailty, the university and the city, Verbum et Ecclesia 34(1), Art. \#855, 9 pages. http://dx.doi.org/10.4102/ve.v34i1.855.

De Beer, S.F. 2014. 'Between life and death': on land, silence and liberation in the capital city, HTS Teologiese Studies/Theological Studies 70(1), Art. \#2075, 7 pages. http://dx.doi.org/10.4102/hts.v70i1.2075.

Du Preez, M. 2013. A Rumour of Spring: South Africa after 20 years of Democracy. Cape Town: Zebra Press.

$\mathrm{Du}$ Toit, J.L. 2010. Local metropolitan government responses to homelessness in South Africa. University of Pretoria. http://hdl.handle.net/2263/14765. [Accessed: 03 November 2014].

Greeff, M. 2010. Information collection: interviewing. In De Vos, A.S., Strydom, H., Fouché, C.B. \& Delport, C.S.L. 2010. Research at grass roots: For the social sciences and human service professions. (Fourth edition). Pretoria: Van Schaik Publishers.

Huchzermeyer, M. 2011. Cities with 'Slums': From informal settlement eradication to a right to the city in Africa. Claremont: UCT Press.

Kaiser, W.C. Jr. 1981. The Promised Land: A Biblical-Historical View. In Bibliotheca Sacra 138 (1981): 302-12.

Kritzinger, J.N.J. 2008. Where does our help come from? Psalm 121 in Tshwane. Missionalia 36(2/3): 337-338.

Lahiff, E. 2007. 'Willing buyer, willing seller': South Africa's failed experiment in market-led agrarian reform, in Third World Quarterly, 28(8), 1577-1597. 
Makiwane, M., Tamasane, T. \& Schneider, M. 2010. Homeless individuals, families and communities: The societal origins of homelessness. Development Southern Africa, 27:1, 39-49, DOI: 10.1080/03768350903519325. [Accessed, 04 November 2014].

Mashau, T.D. 2012. Mission as action in hope in the context of white poverty in Pretoria: A case for Betlehem mission centre. In Acta Theologica Supplementum 16: 54 - 69.

Mashau, T.D. 2014. Reimagining mission in the public square: Engaging hills and valleys in the African City of Tshwane, HTS Teologiese Studies/Theological Studies 70(3), Art.\#2774, 11 pages. http://dx.doi.org/10.4102/hts.v70i3.2774.

Peres, E. \& Du Plessis, C. The threat of slow-changing disturbances to the resilience of African cities. http://www.conference.net.au/cibwbc13/ papers/cibwbc2013_submission_199.pdf [Accessed: 05 November 2014].

Pheko, S.E.M. 1984. The Land is ours: the political legacy of Mangaliso Sobukwe. New York: Pheko \& Associates.

Shivambu, F. (ed.). 2014. The coming revolution: Julius Malema and the fight for economic freedom. Auckland Park: Jacana Media.

Struwig, F.W. \& Stead, G.B. 2001. Planning, designing and reporting research. Cape Town: Maskew Miller Longman.

Sproul, R.C. (ed.). 2005. The Reformation Study Bible. Orlando: Ligonier Ministries.

The Presidency Republic of South Africa. 2014. Twenty year review, South Africa: 1994 - 2014.

West, G. 1995. Biblical hermeneutics of liberation: Modes of reading the Bible in the South African context. Pietermaritzburg: Cluster Publications.

Van Zuydam, L. 2014a. Life on the streets can end - experts. Gauteng, IOL News. http://www.iol.co.za/news/south-africa/gauteng/life-on-thestreets-can-end-experts-1.1704830\#.VFjG9PmUdnE [Accessed: 05 November 2014].

Van Zuydam, L. 2014b. Spotlight on Pretoria's homeless. http://www.iol.co.za/news/south-africa/gauteng/spotlight-onpretoria-s-homeless-1.1704828\#.VFjG9PmUdnE [Accessed: 05 November 2014]. 